\title{
Development of forest-yield maps generated from Global Navigation Satellite System (GNSS)-enabled harvester StanForD files: preliminary concepts
}

Alejandro Olivera* and Rien Visser

\begin{abstract}
Background: The productivity of fast-growing forest plantation stands varies across short distances depending on site and forest characteristics. This indicates that forest managers would benefit from a site-specific approach to forest management. One tool used to characterise such productivity variations is a yield map, and a cost-effective source of data for these maps is automatically collected by harvesters. In order to generate such maps, it is necessary to understand the effect of geospatial accuracy of tree location recorded by the harvester.

Methods: This study investigated data sets from four stands, and very accurate tree location was available for two of these. The tree-location data for the remaining two sites were collected by a harvester and contained some inaccuracies associated with Global Navigation Satellite System (GNSS) recording under forest canopy and the physical dislocation of the GNSS. The GNSS unit is on the cabin of the machine, but the tree is felled using a boom and could be up to $12 \mathrm{~m}$ from the cabin.

Results: A suitable spatial resolution for studying variations in stand productivity, mean tree volume, and stocking rate across stands were established that enabled useful forest-yield maps from harvester data to be developed.

Conclusions: By assessing variability in volume per hectare, stocking rate, and mean tree volume across a range of cell sizes from $10 \times 10$ to $100 \times 100 \mathrm{~m}$, we conclude that a cell length between 30 and $40 \mathrm{~m}$ is suitable for use as a reference when calculating volume per hectare and mean stem volume, while a 60 -m-long cell is more suitable for evaluating stocking density. The variability pattern is consistent for the various accuracy levels. When the known positions of trees are relatively inaccurate, using mean tree volume and stocking rate per cell might be a method for mapping productivity from harvester data.
\end{abstract}

Keywords: Harvester data, Forest-yield map, Eucalyptus, Uruguay

\section{Background}

The length of rotation of fast-growing Eucalyptus spp. plantations in many South American countries has been reduced as a result of intensive breeding programmes and improvements in silvicultural practices. For example, rotation ages of 6-8 years and 9-12 years have been achieved in Brazil and Uruguay, respectively, for pulpwood plantations (Andreoni and Bussoni 2014; Gonçalves et al. 2013). This type of forest management

\footnotetext{
* Correspondence: alejandro.oliverafarias@pg.canterbury.ac.nz New Zealand School of Forestry, University of Canterbury, Private Bag 4800 Christchurch 8140, New Zealand
}

\section{Springer}

(c) 2016 Olivera and Visser. Open Access This article is distributed under the terms of the Creative Commons Attribution 4.0 International License (http://creativecommons.org/licenses/by/4.0/), which permits unrestricted use, distribution, and reproduction in any medium, provided you give appropriate credit to the original author(s) and the source, provide a link to the Creative Commons license, and indicate if changes were made. cides) and operations (agrochemical applications, soil preparation) during the establishment phase. Similar to agricultural crops, forest productivity also varies across short distances depending on both site (soil properties and topography) and forest (genotype, stocking rate, silvicultural practices, etc.) characteristics.

The concept of site-specific management aims to acknowledge the site variability and adjust the silvicultural practices to it instead of managing stands based on average stand characteristics, which is the prevalent approach for plantation-forest management at present. 
Within-stand variability (i.e., over short distances) has been quantified by a number of authors based on intensive sampling. Using site index (SI) as a productivity potential indicator, Ortiz et al. (2006) mapped and related the variability of productivity to soil properties and relief for a 6.3-ha stand of Eucalyptus grandis W. Hill clones in Sao Paulo, Brazil. They used 41 sample plots to assess this stand and found significant correlations between productivity and 6 soil properties, and also with elevation. Barbosa et al. (2012) reported a significant effect of soil $\mathrm{pH}$ on the productivity of a 3-ha stand Pinus caribaea var. hondurensis (Sénécl.) W.H. Barrett \& Golfari in the state of Mato Grosso do Sul, Brazil, following extensive mapping using a grid of 121 points. A 3.6-ha stand of Pinus taeda L. located in Auburn, Alabama, USA was divided into four separate management zones based on a survey of the variation in stocking and productivity across the stand (Brodbeck et al. 2007). These results indicate that forest management in general would benefit from a site-specific management approach to make the process more efficient while with reducing costs and environmental impact. In addition, several other researchers have used different study techniques to assess site variability and have proven, or at least pointed out, the viability of the sitespecific management approach (du Toit et al. 2010; Gonçalves et al. 2012; González Barrios et al. 2015; Vergara 2004). The adoption of site-specific management has some limitations, however. For example, the assessment of variation in soil properties and other forest variables through intensive sampling would be prohibitively expensive for large areas. In addition, forest managers would expect to see clear benefits in production before considering implementation of the additional complexity this approach requires.

In the context of site-specific management, forestproductivity maps are a useful resource to quantify and qualify variations across forested areas. Several techniques have been used to develop forest-yield maps based on plot samples (Mello et al. 2005, 2009; Ortega et al. 2002), a combination of plots and light detection and ranging (LiDAR) (Chen and Zhu 2012; Rombouts et al. 2010), LiDAR when stand age is known, variables derived from satellite imagery combined with environmental surfaces (Watt et al. 2015), and tree surveys (Brodbeck et al. 2007). A promising and cost-effective source of data for mapping productivity is data automatically collected by harvesters when the trees are felled and processed. This topic has been discussed and its benefits explored for forestry plantations (Taylor et al. 2006), but it is yet to be developed.

Productivity maps based on harvester data are used in agriculture. The concept behind the usefulness of yield maps is to evaluate the variation in productivity across the area based on its real harvested production. Having this information at hand provides practitioners with useful information to manage sites specifically according to their characteristics (topography, soil, water availability, fertility, etc.) and potential for improving profitability and reducing environmental impact through more targeted applications of fertilisers and or pesticides. The required equipment for collecting data for mapping productivity is a harvester equipped with a yield sensor (determined using either mass flow or volumetric methodology) and a global navigation satellite system (GNSS), preferably with a differential correction system to improve accuracy (Bongiovanni and Lowenberg-DeBoer 2006; Griffin 2010; Zhang et al. 2002).

Similar to agricultural harvesters, modern forest harvesters are equipped with a standard software system (StanForD) to automatically record data during the operation. Developed in Scandinavia in 1988, StanForD is now used in many countries (Skogforsk 2014) and has become a de facto standard. Harvesters that comply with this standard have been widely adopted in harvesting operations in Uruguay, Brazil, and Chile. In Uruguay, although there are no official data available, it is estimated that over $60 \%$ of the 12 million cubic metres of forest harvested each year use harvesters (MGAP DGF 2015). Hence, there is a substantial potential to use the data collected in these countries as an input into site-specific management plans. StanForD produces more than 20 types of files that record data from the harvesting operation and the forest, including .pri (production individual files) and .stm (individual stem data) (Skogforsk, Olivera and Visser unpublished 2014 ${ }^{1}$ ). These files can be used by forestry companies and contractors to manage various aspects of production, and have been used in numerous research applications (Olivera et al. 2015). Stem files (.stm) compress data for each individual harvested tree including the following: stem identification number, diameter at breast height (DBH), diameter sections measured at $10-\mathrm{cm}$ intervals along the stem, stem volume, individual log volume, and log classification. Moreover, when harvesters are equipped with a GNSS receiver, geographic coordinates of each tree at felling time are included in the files. Stem (.stm) files also contain manually inputted information such as species and site identification.

The data collection outputs of agricultural harvesters are different from forest harvesters. The results of data collected by agricultural harvesters may be provided in terms of mass (tons or kilogrammes) per unit of area (acres, hectares) (Bragachini et al. 2006; Griffin 2010; Whelan and Taylor 2013). Yield maps can be generated by removing points of erroneous yield estimations (caused by harvester turns and overlaps, narrow finishes, machine speed, GNSS positional errors, and empty spaces or voids) and interpolating productivity values from the original machine records (Lyle et al. 
2014; Robinson and Metternicht 2005). Forest harvesters, on the other hand, do not output units of volume per hectare; instead, they record individual tree data and a spatial location. These types of data are subject to two sources of error:

a) GNSS location. The GNSS is typically mounted in the cabin of the machine, but the tree is felled by the harvester head, which is mounted at the end of a boom that can be up to $12 \mathrm{~m}$ long. Therefore, the location of the tree will be incorrectly defined by a distance equivalent to the extension of the boom.

b) GNSS accuracy. The accuracy of commonly used grades of GNSS locators operated in similar conditions (i.e., forest environment with partial sky coverage) averages between 3 and $6 \mathrm{~m}$ with standard deviations up to $12 \mathrm{~m}$ (Veal et al. 2001; Wing 2008; Wing et al. 2005; Yoshimura and Hasegawa 2003). Even with devices capable of using the US global positioning system (GPS) and/or the Russian Global Navigation Satellite System (GLONASS) for positioning, Kaartinen et al. (2015) determined an accuracy range between 4 and $9 \mathrm{~m}$. These errors make accurately evaluating the distribution of volume and stocking per hectare a challenging task.

Therefore, prior to developing productivity maps from GNSS-enabled harvester data, it is necessary to establish a spatial resolution that can overcome the limitations in tree accuracy location from this type of data. The overall objectives of this study are to improve our understanding of spatial resolution for studying variations in volume and stocking density across forested stands and to establish guidelines for actual spatial resolution that would allow the development of fit-for-purpose forestyield maps from harvester data.

\section{Methods}

Study sites

Four sets of data comprising information on individual trees were collected/generated. Stand 1 is a 3.6-ha area planted on a $15 \%$ slope site located $9.6 \mathrm{~km}$ north of Auburn, Alabama, USA ( $32^{\circ} 41^{\prime} 43^{\prime \prime} \mathrm{N}, 85^{\circ} 30^{\prime} 11^{\prime \prime} \mathrm{W}$ ). At the data collection time (pre-2007), the stand was age 25 years and was thinned at age 16 years (Table 1 ). The position of each Pinus taeda tree within the stand was measured with sub-centimetre accuracy as described in Brodbeck et al. (2007). The information contained in this dataset were: tree identity, latitude, longitude and elevation above sea level ( $X, Y$, and $Z$ coordinates, respectively), and DBH. With this information, height and volume of each tree were calculated using the same equations for pulpwood described by Brodbeck et al. (2007)and shown as Eqs. 1 and 2, respectively,

$$
\begin{aligned}
& \text { Height }(m)=12.689+0.253 * \mathrm{DBH} \\
& \text { Volume }\left(m^{3}\right)=0.23233 * \mathrm{DBH}^{2} * \text { height }
\end{aligned}
$$

For both equations, DBH is in centimetres.

Stand 2 was artificially generated using ArcGIS 10.2.2 software (Esri Inc 2014) for a stand of 6.65 ha. Initial tree spacing was uniform with $3.5 \mathrm{~m}$ between rows and $2.15 \mathrm{~m}$ between trees in the same row, resulting in a theoretical stocking of 1328 trees $\mathrm{ha}^{-1}$. This was randomly reduced by $27 \%$ to 967 trees $\mathrm{ha}^{-1}$ to simulate a typical level of mortality. Tree volume was defined using an independent dataset obtained from .stm records from a stand (not included in the study) planted with Eucalyptus dunnii (Maiden). In addition, individual tree volume was increased in the direction northeast to southwest to deliberately create a spatial trend in-stand volume variation.

Stands $3\left(32^{\circ} 33^{\prime} 18^{\prime \prime} \mathrm{S}, 57^{\circ} 24^{\prime} 19^{\prime \prime} \mathrm{W}\right)$ and $4 .\left(32^{\circ} 32^{\prime}\right.$ $\left.41^{\prime \prime} \mathrm{S}, 57^{\circ} 24^{\prime} 04^{\prime \prime} \mathrm{W}\right)$ are both even-aged, first-rotation forest plantations located in the northern part of the Rio

\begin{tabular}{|c|c|c|c|c|}
\hline & Stand 1 & Stand $2^{a}$ & Stand 3 & Stand 4 \\
\hline Location & Auburn, AL, USA & $\mathrm{n} / \mathrm{a}$ & Rio Negro, Uruguay & Rio Negro, Uruguay \\
\hline Species & Pinus taeda (L.) & $\mathrm{n} / \mathrm{a}$ & Eucalyptus dunnii (Maiden) & Eucalyptus maidenii (F. Muell) \\
\hline Age (years) & 25 & $\mathrm{n} / \mathrm{a}$ & 19 & 19 \\
\hline Year of data collection & Pre-2007 & $\mathrm{n} / \mathrm{a}$ & 2014 & 2014 \\
\hline Area (ha) & 3.6 & 6.65 & 6.65 & 8.05 \\
\hline Average stocking rate (no. trees ha ${ }^{-1}$ ) & 661 & 967 & 967 & 899 \\
\hline Thinned & at age 16 & no & no & no \\
\hline Volume studied $^{\mathrm{b}}$ & Total volume & Merchantable volume & Merchantable volume & Merchantable volume \\
\hline Average volume $\left(\mathrm{m}^{3} \mathrm{ha}^{-1}\right)$ & 157 & 506 & 464 & 213 \\
\hline Mean stem volume $\left(\mathrm{m}^{3}\right)$ & 0.24 & 0.52 & 0.48 & 0.24 \\
\hline
\end{tabular}

Table 1 Characteristics of the four studied stands

a $n / a$ not applicable

${ }^{\mathrm{b}}$ Merchantable volume refers to volume of commercial logs only 
Negro department in Uruguay. The original spacing of both stands was equal to the spacing used to generate Stand 2; the average stocking at harvesting time was 967 and 899 trees $\mathrm{ha}^{-1}$ for Stands 3 and 4, respectively. Stand 3 contained E. dunnii and had an area of 6.65 ha, while Stand 4 was comprised of Eucalyptus maidenii (F. Muell) and had an area of $8.05 \mathrm{ha}$. Records relating to the trees in Stands 3 and 4 were obtained from .stm files acquired using a single-grip harvester Ponsse Ergo 8W equipped with a combined GSM-GNSS antenna fitted on the cabin for geospatial data collection and communication. The control system used was Opti4G 4.715 (Ponsse Oyj, nd.) which complies with the StanForD standard. All harvested trees were debarked and cross-cut for pulpwood logs. Further details of each stand are provided in Table 1. The analysis variables are: volume per hectare $\left(\mathrm{m}^{3} \mathrm{ha}^{-1}\right)$, stocking $\left(\right.$ trees $\left.\mathrm{ha}^{-1}\right)$, and mean tree volume $\left(\mathrm{m}^{3}\right)$.

Data for Stands 1 and 2 were used to study the variability of these three variables for the analysis of a suitable spatial resolution to study them. The results of Stands 1 and 2 where then compared with Stands 3 and 4 to verify if there are differences in pattern attributed to the accuracy of tree records.

\section{Cell-size analysis}

A map showing productivity variation across a stand can be generated directly using the position of each tree by dividing the stand area into cells of equal size and summing the volume of all trees within each cell. To determine a suitable cell size for productivity mapping, a cell-size analysis was carried out by dividing each stand in square cells of increasing length: $10,20,30,40,60$, and $100 \mathrm{~m}$ (Fig. 2).

The cell-size analysis was done in two steps. Firstly, the tool Point to Raster in ArcGIS 10.2.2 (Esri Inc 2014) was used which converts a point vector layer (stem records) into a raster layer giving the value of a single variable to each cell. This step was repeated for each combination of

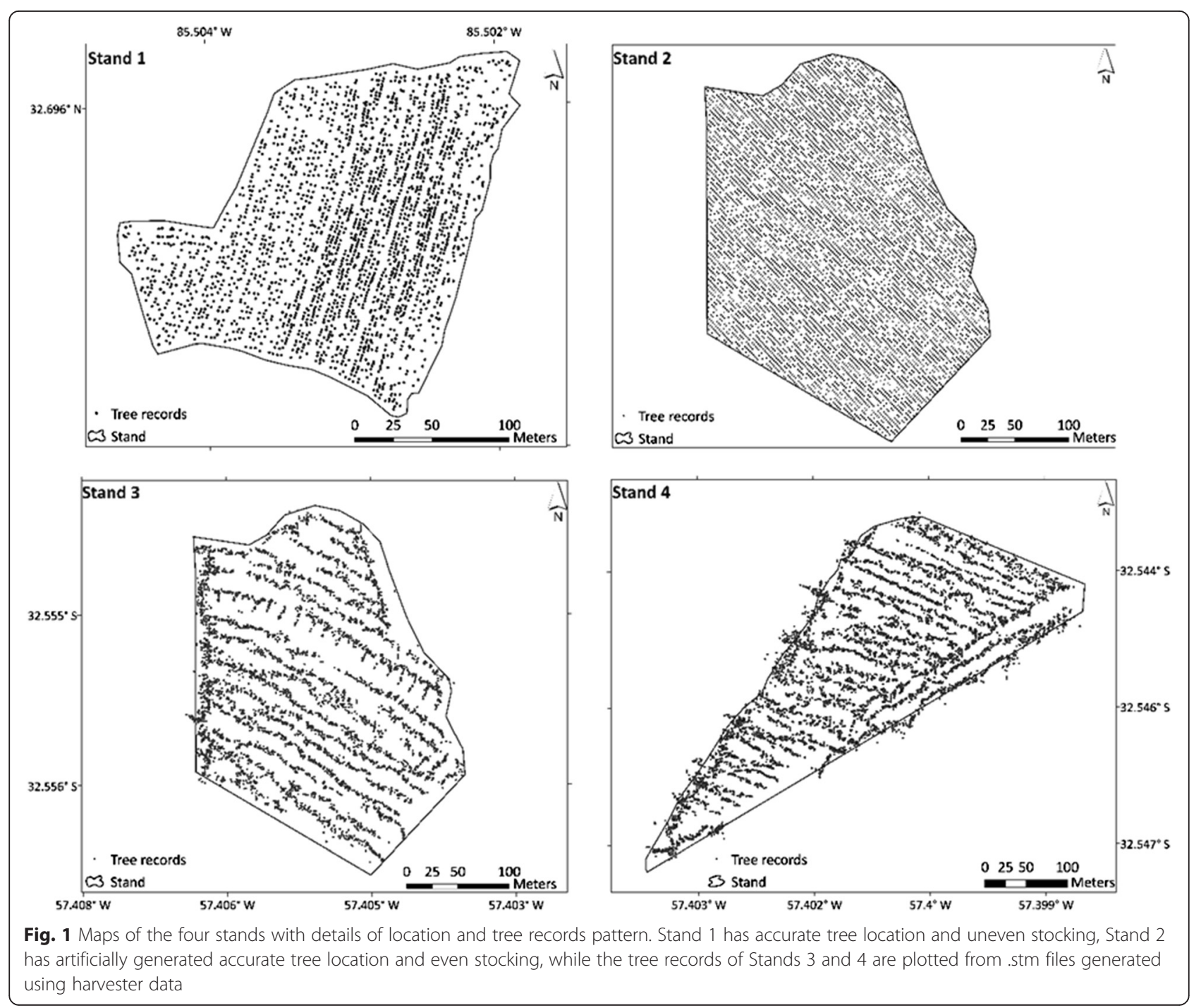


variable (3) cell size (6) and stand (4) (72 times). The second step was to analyse this information using Excel software (Microsoft Corporation, USA). This analysis assessed how the coefficient of variation $(\mathrm{CV})$ of each variable changed as the cell size increased within the stand.

\section{Results and discussion}

The position of each tree in Stand 1 was measured empirically with high accuracy, and the position of each tree in Stand 2 was generated artificially and so was also accurately documented. Tree position in the remaining two stands (3 and 4) had a much lower level of geospatial accuracy because the data were collected indirectly by a harvester. The difference between surveyed or artificially generated stand data, and harvester data can be readily seen in Fig. 1. Maps of Stand 1 and 2 clearly show the trees in planted rows. In contrast, the maps of Stands 3 and 4 show the path of the harvester as the trees are felled in addition to the two sources of location error outlined above.

\section{Cell-size distribution}

The results of the cell-size analysis for the three variables showed that the CV is expected to decrease as cell size increases until it reaches the size and the overall average of the stand. It is expected that the CV will stabilise, which indicates that the variability due to cell size is small and the remaining variability is from the stand itself.

Volume per hectare and stocking per hectare were calculated only from cells that were completely within the boundaries of Stands 1 and 2 (Fig. 2 shows Stand 1 as an example). This approach was used because these variables are related to the total cell area and are expressed per hectare. Mean stem volume from cells of 20 to $100 \mathrm{~m}$ in length was calculated using data from all cells containing 30 or more stem records, even though they may have fallen partially outside the stand boundary. The number of cells included from each stand for each variable is shown in Table 2. As the cell size increased, the proportion of useable cells for calculating volume and stocking decreased because of the increasing number of cells that fall partially outside of the stand (Fig. 2). Conversely, the proportion of useable cells for calculating mean stem volume was stable for all cell sizes.

A large number of empty cells existed in Stands 3 and 4 when a cell length of $10 \mathrm{~m}$ was applied (Table 2). This is unlikely to represent reality because the area is a plantation forest without thinning and with gaps excluded by the company remapping executed in 2013 (Managers pers. Comm.); thus, there should be very few, if any, empty cells.

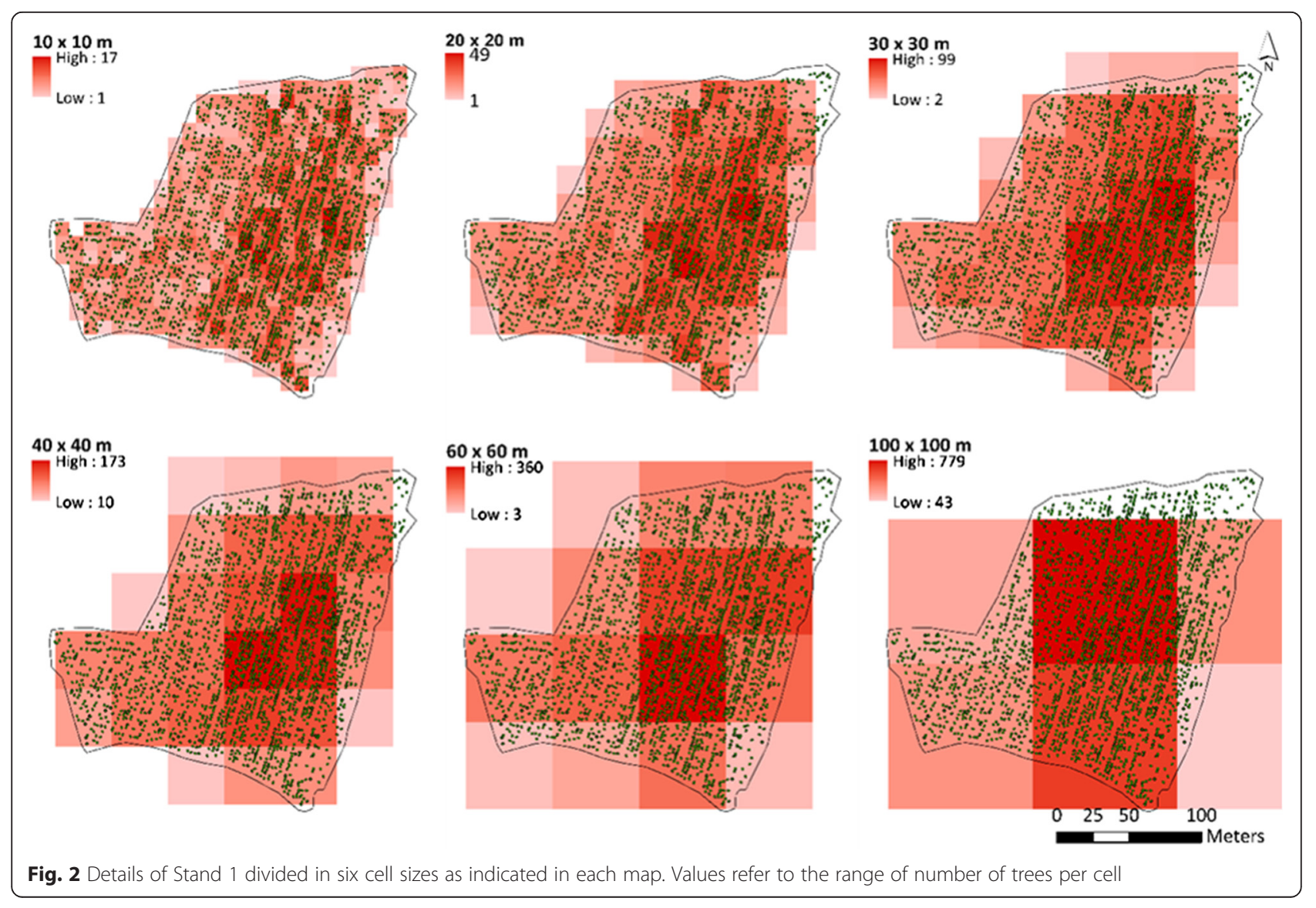


Table 2 Detail of cell divisions for the four stands and six cell sizes

\begin{tabular}{|c|c|c|c|c|c|c|c|}
\hline & Cell length $(m)$ & 10 & 20 & 30 & 40 & 60 & 100 \\
\hline \multirow[t]{4}{*}{ Stand 1} & Number of cells & 359 & 103 & 52 & 29 & 15 & 6 \\
\hline & Number of cells_-no edges & 311 & 67 & 27 & 13 & 3 & 1 \\
\hline & Number of empty cells & 1 & 0 & 0 & 0 & 0 & 0 \\
\hline & Cells used for mean volume calculation & 311 & 63 & 34 & 24 & 15 & 6 \\
\hline \multirow[t]{4}{*}{ Stand 2} & Number of cells & 699 & 188 & 88 & 53 & 23 & 11 \\
\hline & Number of cells_-no edges & 621 & 146 & 58 & 32 & 11 & 3 \\
\hline & Number of empty cells & 0 & 0 & 0 & 0 & 0 & 0 \\
\hline & Cells used for mean volume calculation & 621 & 161 & 76 & 47 & 22 & 11 \\
\hline \multirow[t]{4}{*}{ Stand 3} & Number of cells & 562 & 174 & 83 & 51 & 22 & 9 \\
\hline & Number of cells_-no edges & 551 & 166 & 61 & 29 & 13 & 4 \\
\hline & Number of empty cells & 72 & 2 & 0 & 0 & 0 & 0 \\
\hline & Cells used for mean volume calculation & 562 & 166 & 75 & 47 & 22 & 9 \\
\hline \multirow[t]{4}{*}{ Stand 4} & Number of cells & 791 & 241 & 122 & 75 & 36 & 15 \\
\hline & Number of cells—no edges & 791 & 207 & 71 & 33 & 14 & 4 \\
\hline & Number of empty cells & 93 & 2 & 0 & 0 & 0 & 0 \\
\hline & Cells used for mean volume calculation & 791 & 207 & 95 & 59 & 33 & 13 \\
\hline
\end{tabular}

For these two stands, there were also empty cells when the cell length was $20 \mathrm{~m}$. When cell length was increased to either 60 or $100 \mathrm{~m}$, the results were similar to those obtained for the overall average of the whole stand. In addition, the number of cells that fell completely inside the stand decreased such that only one 100-m-long cell fell completely within Stand 1 (Fig. 2).

\section{Volume per hectare}

Increasing cell length only slightly affected the calculated average volume per hectare, with variation within $\pm 10 \%$ in the majority of cases (22 out of 24) (Table 3 and Fig. 3) compared with the empirical values (Table 1). However, as the cell length increased, the $\mathrm{CV}$ of volume per hectare decreased consistently for all stands independently of the type of data that was used (Fig. 4). However, the range of this $\mathrm{CV}$ differed for the various stand types as the cell size changed. Both stands that have accurate tree location (Stands 1 and 2) produced a lower CV at 10-m cell length (32-33\%) than the harvester data stands (Stands 3 and 4) (67-77 \%) (Fig. 4). The CV decreased when the cell length was increased to $20 \mathrm{~m}$ for all stands. The values of $\mathrm{CV}$ continued to decrease at a similar rate when cell length increased to $30 \mathrm{~m}$ for Stands 3 and 4, but the decrease reached an asymptote for Stands 1 and 2 . The CV decreased for all stands when the cell length increased from 30 to $60 \mathrm{~m}$. This pattern of variation suggests that cell length contributes more to the overall variability in small (10 to $20 \mathrm{~m}$ long) cells. For cells 30 to $60 \mathrm{~m}$ long, the variability in productivity can be attributed

Table 3 Average values of the three variables for each stand and each cell size

\begin{tabular}{|c|c|c|c|c|c|c|c|}
\hline & Cell length (m) & 10 & 20 & 30 & 40 & 60 & 100 \\
\hline \multirow[t]{3}{*}{ Stand 1} & Volume per hectare $\left(\mathrm{m}^{3}\right)$ & 168 & 169 & 167 & 168 & 170 & - \\
\hline & Stocking rate (stems ha ${ }^{-1}$ ) & 733 & 760 & 770 & 793 & 792 & - \\
\hline & Mean stem volume $\left(\mathrm{m}^{3}\right)$ & 0.26 & 0.25 & 0.25 & 0.25 & 0.26 & 0.26 \\
\hline \multirow[t]{3}{*}{ Stand 2} & Volume per hectare $\left(\mathrm{m}^{3}\right)$ & 507 & 513 & 512 & 509 & 523 & 531 \\
\hline & Stocking rate $\left(\right.$ stems ha ${ }^{-1}$ ) & 968 & 966 & 968 & 966 & 961 & 957 \\
\hline & Mean stem volume $\left(\mathrm{m}^{3}\right)$ & 0.52 & 0.53 & 0.53 & 0.52 & 0.52 & 0.51 \\
\hline \multirow[t]{3}{*}{ Stand 3} & Volume per hectare $\left(\mathrm{m}^{3}\right)$ & 556 & 459 & 462 & 450 & 455 & 451 \\
\hline & Stocking rate $\left(\right.$ stems ha $\left.{ }^{-1}\right)$ & 1162 & 981 & 974 & 952 & 977 & 1006 \\
\hline & Mean stem volume $\left(\mathrm{m}^{3}\right)$ & 0.50 & 0.48 & 0.48 & 0.48 & 0.47 & 0.45 \\
\hline \multirow[t]{3}{*}{ Stand 4} & Volume per hectare $\left(\mathrm{m}^{3}\right)$ & 217 & 200 & 196 & 193 & 184 & 203 \\
\hline & Stocking rate $\left(\right.$ stems ha ${ }^{-1}$ ) & 914 & 842 & 826 & 809 & 778 & 850 \\
\hline & Mean stem volume $\left(\mathrm{m}^{3}\right)$ & 0.24 & 0.24 & 0.24 & 0.24 & 0.23 & 0.24 \\
\hline
\end{tabular}



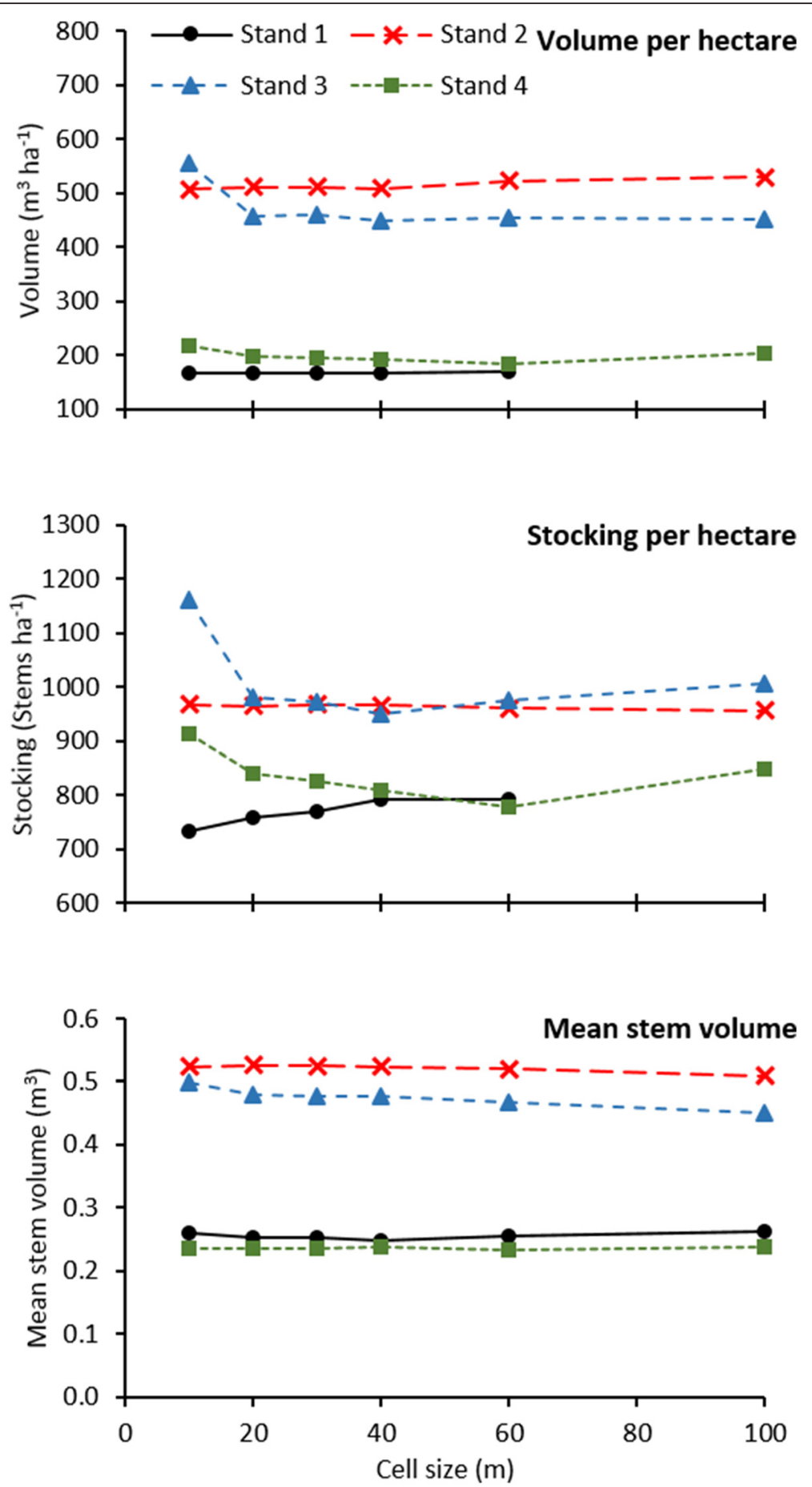

Fig. 3 Changes in averages for the three variables as cell length increases from 10 to $100 \mathrm{~m}$ for each of the four stands. Note that there are no values of volume per hectare and stocking per hectare for a 100-m-long cell in Stand 1 because there is only one cell

to other causes from the environment or the forest such as soil characteristics, topography, stocking, and even tree-location accuracy for Stands 3 and 4. At 60-m cell length, however, the number of cells that fit in a small stand-Stand 1 for example-is reduced, resulting in a coarse resolution for further analysis of volume. For a 100-m cell length, the CV is the lowest for Stands 2 to 4 as the area of each cell represents more the average of the stand, and the number of cells is reduced (Table 2).

As such, when tree locations are accurately recorded, using a cell length between 30 and $40 \mathrm{~m}$ constitutes a 

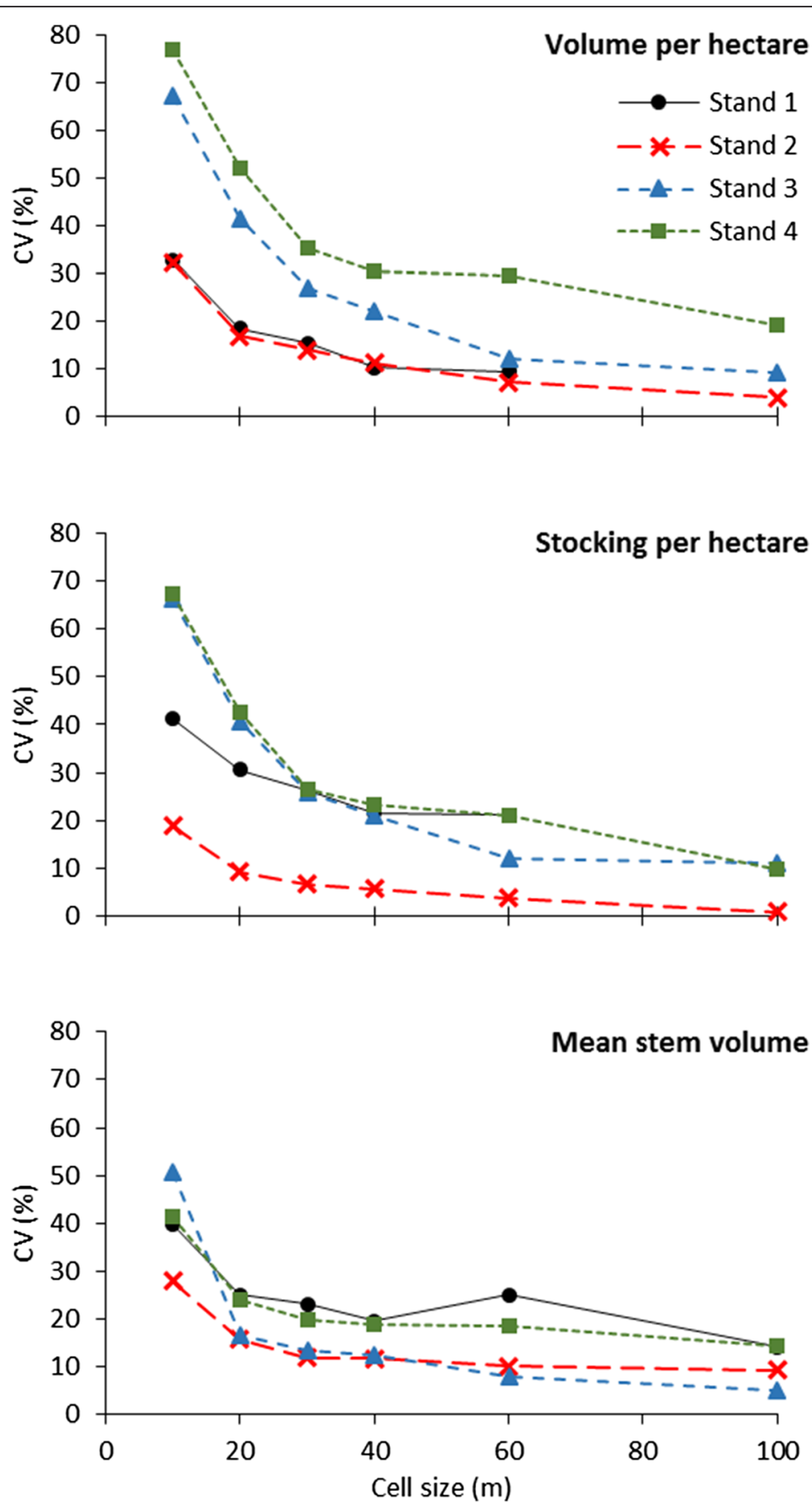

Fig. 4 Changes in the coefficient of variation (CV) for the three variables as cell length increases from 10 to $100 \mathrm{~m}$ for each of the four stands. Note that there are no values of volume per hectare and stocking per hectare for a 100-m-long cell in Stand 1 because there is only one cell

reasonable unit size to subdivide a stand to study the volume variation (productivity) across its area.

\section{Stocking rate}

Coefficient of variation values of stocking rate for all stands followed a similar pattern as for volume, i.e., the
CV diminished as cell size increased (Fig. 4). Also, the calculated averages were stable for Stands 2, 3, and 4 (Table 3 and Fig. 3) and were similar to the overall empirical average (Table 1). For Stand 1, however, cells of all the lengths tested resulted in overestimation of the average stocking rate by 11 to $20 \%$ because the edges of 
the stand that had lower stocking rates (Figs. 1 and 2) were excluded from the analysis as they were not totally within the stand.

The variability of the stocking rate decreased rapidly when the cell length was increased from 10 to $30 \mathrm{~m}$ for Stands 1, 3, and 4, whereas for Stand 2, this rapid decease occurred in the transition from a 10 to $20 \mathrm{~m}$ cell length. Low values of $\mathrm{CV}$, ranging from 19 to $1 \%$, across the different cell lengths in Stand 2 reflected the artificially generated even distribution of trees across this stand. A cell length of $10 \mathrm{~m}$ (and even one of $20 \mathrm{~m}$ ) does have an effect as reflected in the higher $\mathrm{CV}$ for these cell lengths. In the case of Stand 1, the CV fell as cell length increased from 10 to $40 \mathrm{~m}$ then stabilised at a value around $21 \%$. This result reflected the real variation in stocking rate across this stand, variation that is clearly shown in Figs. 1 and 2. The $\mathrm{CV}$ value for Stand 3 decreased as cell length increased up to $60 \mathrm{~m}$, whereas the $\mathrm{CV}$ value stabilised for cells between 30 and $60 \mathrm{~m}$ long in Stand 4.

For Stand 1, which has accurate tree location and uneven stocking rate, the most suitable cell length for stocking rate analysis is 40 to $60 \mathrm{~m}$ as the $\mathrm{CV}$ is stable over this range and suggests that the remaining variation $(\mathrm{CV}$ of $21 \%$ ) is independent of cell size. For Stand 2, which has a homogeneous stocking density across the stand and accurate tree location, a cell length of $30 \mathrm{~m}$ or higher is suitable. If the distribution is not known a priori (as in the case of real stands using harvester data), however, working with $60-\mathrm{m}$ cell length is a suitable option for mapping stocking levels, as was found for Stand 3. For Stand 4, the CV was stable (20-26\%) for cells between 30 and $60 \mathrm{~m}$ in length, suggesting that a cell size in this range would be suitable for stocking density analysis. The stable pattern for Stands 3 and 4 also shows that the errors in GNSS accuracy affecting the variability of the stocking rate may be negligible at this level of resolution.

Another important factor to consider is the size of the stand (or area evaluated). Stands smaller than 4 ha, such as Stand 1, would contain a very low number of $60-\mathrm{m}$ long cells (Fig. 2 and Table 2). This is not desirable if there is a variation in stocking across the stand. In this case, the use of 40-m-long cells is advisable.

\section{Mean tree volume}

As with volume and stocking, mean tree volume varied considerably when 10-m-long cells were used (Figs. 3 and 4). This variation decreased dramatically when cell length was increased to $20 \mathrm{~m}$ and fell steadily as cell length increased up to $100 \mathrm{~m}$. Variation was observed even with 100 -m-long cells, which suggests that there is an effect from the environment or the forest itself affecting stem mean volume in all four stands. These results suggested that a cell length between 20 and $40 \mathrm{~m}$ would be suitable for further analysis. At smaller cell length, the high CV and low number of trees per cell would bias any analysis. Above 40-m length, the cell sizes are too large to capture any variation across the stand due to the large proportion of the stand each cell represents (Table 2).

\section{Conclusions}

Based on the changes in $\mathrm{CV}$ across the studied range of cell sizes, we conclude that a cell length between 30 and $40 \mathrm{~m}$ is suitable for use as a reference when estimating volume per hectare (productivity) and mean stem volume to further compare and develop the concepts of forest-productivity maps. For evaluating stocking rate, the use of 60-m-long cells is more suitable in situations where variation in stocking across an area is unknown, such as when using harvester data. For stands smaller than 4 ha, a 40 -m-long cell might be used to obtain a greater number of points.

The pattern of $\mathrm{CV}$ variation was consistent in both types of stands (accurate tree location and harvester data) for all three variables. However, there is still some uncertainty as to what proportion of the variation can be attributed to the environment and tree-location accuracy for Stands 3 and 4 . However, this study has shown that even if the position of trees is not accurate, using mean tree volume and stocking rate per cell can be a method for mapping productivity from harvester data. An idealised future study would fully survey all trees in a stand and then capture the corresponding harvester data set. This would allow a more complete understanding of what variation is attributable to the geospatial inaccuracy of the harvester versus the actual variation in the stand.

\section{Endnotes}

${ }^{1}$ Olivera, A, Visser, R. (2014). Integration of Harvester Data and Geospatial Information. Rotorua, New Zealand: Future Forests Research Ltd.

\section{Competing interests \\ The authors declare that they have no competing interests.}

\section{Authors' contributions}

AO sourced the harvester data, created the Stand 2 data, carried out the analysis, and wrote the manuscript. RV conceived the idea for the analysis, sourced the Stand 1 data, and reviewed the manuscript. Both authors read and approved the final version of the manuscript.

\section{Authors' information}

$\mathrm{AO}$ is a PhD candidate from Uruguay whose research project is looking at "Exploring opportunities for the integration of GNSS with forest harvester data to improve forest management". He has worked for over 10 years in the forest industry in his home country. RV is an Associate Professor and the Director of Studies at the Forest Engineering degree at the New Zealand School of Forestry, University of Canterbury; he is the senior supervisor of AO in his PhD project.

\section{Acknowledgements}

We would like to thank Timothy McDonald and Christian Brodbeck from Auburn University Alabama, USA for providing the data presented as Stand 1. We also want to thank Future Forests Research (FFR) Rotorua New Zealand for supporting this project and the Uruguayan forest company Montes del 
Plata for authorising the use of the harvester data used in the study and the provision of inventory data. Special thanks to Ponsse Uruguay S.A. for their support and regular provision of harvester data from the operations in Uruguay.

Received: 25 September 2015 Accepted: 12 January 2016

Published online: 27 January 2016

\section{References}

Andreoni, M. I., \& Bussoni, A. (2014). Economic assessment of two breeding programs in Eucalyptus grandis. Agrociencia Uruguay, 18, 153-162.

Barbosa, C. E. M., Ferrari, S., Carvalho, M. P., Picoli, P. R. F., Cavallini, M. C., Benett, C. G. S., et al. (2012). Relationship between pine wood yield and physical and chemical traits of a Brazilian cerrado oxisoil. Revista Arvore, 36, 25-35.

Bongiovanni, R., \& Lowenberg-DeBoer, J. (2006). Adopcion de la agricultura de precision en el cono sur de America. In R. Bongiovanni, E. C. Mantovani, S. Best, \& Á. Roel (Eds.), Agricultura de precisión: integrando conocimientos para una agricultura moderna y sustentable (pp. 203-218). Montevideo, Uruguay: Imprenta Mosca y Cia.

Bragachini, M., Méndez, A., Scaramuzza, F., \& Proietti, F. (2006). Monitores de rendimiento y elaboracion de mapas. In R. Bongiovanni, E. C. Mantovani, S. Best, \& A. Roel (Eds.), Agricultura de precisión: integrando conocimientos para una agricultura moderna y sustentable (pp. 43-54). Montevideo, Uruguay: Imprenta Mosca y Cia.

Brodbeck, C., Fulton, J., Shaw, J., McDonald, T., \& Rodekohr, D. (2007). Timber mapping for site-specific forest management. Paper presented at the ASABE Annual International Meeting, Minneapolis, Minnesota, USA. https://eng.auburn. edu/files/file1049.pdf.

Chen, Y., \& Zhu, X. (2012). Site quality assessment of a Pinus radiata plantation in Victoria, Australia, using LiDAR technology. Southern Forests, 74(4), 217-227. doi:10.2989/20702620.2012.741767.

du Toit, B., Smith, C. W., Little, K. M., Boreham, G., \& Pallett, R. N. (2010). Intensive, site-specific silviculture: manipulating resource availability at establishment for improved stand productivity. A review of South African research. Forest Ecology and Management, 259(9), 1836-1845. doi:10.1016/j.foreco.2009.07.015.

Esri Inc. (2014). ArcGIS 10.2.2 for Desktop (Version 10.2.2) [Geographical Information System]. Redlands, CA, USA: Esri.

Gonçalves, J. L. M., Alvares, C. A., Gonçalves, T. D., Moreira, R. M. Mendes, J. C. T., \& Gava, J. L. (2012). Soil and productivity mapping of Eucalyptus grandis plantations, using a geographic information system. Scientia Forestalis, 40(94), 187-201.

Gonçalves, J. L. M., Alvares, C. A., Higa, A. R., Silva, L. D., Alfenas, A. C., Stahl, J., et al. (2013). Integrating genetic and silvicultural strategies to minimize abiotic and biotic constraints in Brazilian eucalypt plantations. Forest Ecology and Management, 301, 6-27. doi:10.1016/j.foreco.2012.12.030.

González Barrios, P., Pérez Bidegain, M., \& Gutiérrez, L. (2015). Effects of tillage intensities on spatial soil variability and site-specific management in early growth of Eucalyptus grandis. Forest Ecology and Management, 346, 41-50. doi:10.1016/j.foreco.2015.02.031.

Griffin, T. W. (2010). The spatial analysis of yield data. In M. A. Oliver (Ed.), Geostatiscal applications for precision agriculture (pp. 89-116). United Kingdon: Springer.

Kaartinen, H., Hyyppä, J., Vastaranta, M., Kukko, A., Jaakkola, A., Yu, X., et al. (2015). Accuracy of kinematic positioning using Global Satellite Navigation Systems under forest canopies. Forests, 6(9), 3218-3236.

Lyle, G., Bryan, B. A., \& Ostendorf, B. (2014). Post-processing methods to eliminate erroneous grain yield measurements: review and directions for future development. Precision Agriculture, 15(4), 377-402. doi:10.1007/s11119-013-9336-3.

Mello, J. M., Batista, J. L. F., de Oliveira, M. S., \& Ribeiro, P. J., Jr. (2005). Spatial dependence sudy of Eucalyptus grandis dendrometric characteristics. Cerne, 11(2), 113-126

Mello, J. M., Diniz, F. S., de Oliveira, A. D., de Mello, C. R., Scolforo, J. R. S., \& Acerbi, F. W., Jr. (2009). Continuidade espacial para características dendrométricas (numero de fustes e volume) em plantios de Eucalyptus grandis. Revista Árvore, 33, 185-194.

MGAP DGF. (2015). Extracion, produccion y consumo. Statistics and Market. http://www.mgap.gub.uy/portal/page.aspx?2,dgf,dgf-extraccion-produccionconsumo,O,es,0, Accessed 27 Jan 2015.

Olivera, A., Visser, R., Acuna, M., \& Morgenroth, J. (2015). Automatic GNSS enabled harvester data collection as a tool to evaluate factors affecting harvester productivity in an Eucalyptus spp. harvesting operation in Uruguay. International Journal of Forest Engineering. doi:10.1080/14942119.2015. 1099775.
Ortega, J. A., Foster, W., \& Ortega, R. (2002). Definicion de sub-rodales para una silvicultura de precision: una aplicacion del metodo Fuzzy k-means [Definition of sub stands for precision forestry: a Fuzzy k-means method application]. Ciencia e Investigacion Agraria, 29(1), 35-44.

Ortiz, J. L., Vettorazzi, C. A., Couto, H. T. Z., \& Goncalves, J. L. M. (2006). Spatial relationship between productive potential of eucalyptus and attributes of soil and relief. Scientia Forestalis, 72, 67-79.

Ponsse Oyj. (nd.). Opti4G 4.715, Harvester software. Vieremä, Finland.

Robinson, T. P., \& Metternicht, G. (2005). Comparing the performance of techniques to improve the quality of yield maps. Agricultural Systems, 85(1), 19-41. doi:10.1016/j.agsy.2004.07.010.

Rombouts, J., Ferguson, I. S., \& Leech, J. W. (2010). Campaign and site effects in LiDAR prediction models for site-quality assessment of radiata pine plantations in South Australia. International Journal of Remote Sensing, 31(5), 1155-1173. doi:10.1080/01431160903380573.

Skogforsk. (2014). StanForD. http://www.skogforsk.se/english/projects/stanford/. Accessed 11 August 2014].

Taylor, S. E., McDonald, T. P., Fulton, J. P., Shaw, J. N., Corley, F. W., \& Brodbeck, C. J. (2006). Precision forestry in the southeast U.S. Paper presented at the International Precision Forestry Symposium - Precision Forestry in plantations, semi-natural and natural forests., Stellenbosch South Africa.

Veal, M. W., Taylor, S. E., McDonald, T. P., McLemore, D. K., \& Dunn, M. R. (2001). Accuracy of tracking forest machines with GPS. Transactions of the ASAE, 44(6), 1903-1911.

Vergara, J. T. (2004). Silvicultural options to increase the profit of plantation forest. Bosque, 25(2), 101-113.

Watt, M. S., Dash, J. P., Bhandari, S., \& Watt, P. (2015). Comparing parametric and non-parametric methods of predicting Site Index for radiata pine using combinations of data derived from environmental surfaces, satellite imagery and airborne laser scanning. Forest Ecology and Management, 357, 1-9. doi:10.1016/j.foreco.2015.08.001

Whelan, B., \& Taylor, J. (2013). Precision agriculture for grain production systems. Victoria, Australia: CSIRO publishing.

Wing, M. G. (2008). Consumer-grade Global Positioning Systems (GPS) receiver performance. Journal of Forestry, 106(4), 185-190.

Wing, M. G., Eklund, A., \& Kellogg, L. D. (2005). Consumer-grade Global Positioning System (GPS) accuracy and reliability. Journal of Forestry, 103(4), 169-173.

Yoshimura, T., \& Hasegawa, H. (2003). Comparing the precision and accuracy of GPS positioning in forested areas. Journal of Forest Research, 8(3), 147-152. doi:10.1007/s10310-002-0020-0.

Zhang, N., Wang, M., \& Wang, N. (2002). Precision agriculture-a worldwide overview. Computers and Electronics in Agriculture, 36(2-3), 113-132. doi:10. 1016/S0168-1699(02)00096-0.

\section{Submit your manuscript to a SpringerOpen ${ }^{\mathcal{O}}$ journal and benefit from:}

- Convenient online submission

- Rigorous peer review

- Immediate publication on acceptance

- Open access: articles freely available online

- High visibility within the field

- Retaining the copyright to your article

Submit your next manuscript at $\gg$ springeropen.com 